\title{
A Reliability and Validity Study of the Turkish Version of the Parenting Scale
}

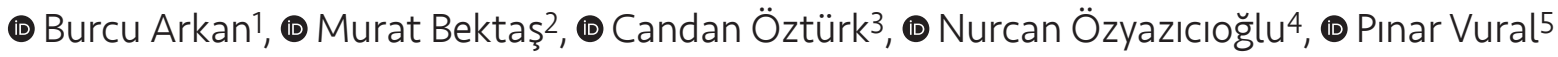

1Bursa Uludağ University Faculty of Health Sciences, Department of Psychiatric Nursing, Bursa, Turkey 2Dokuz Eylül University Faculty of Nursing, Department of Paediatric Nursing, İzmir, Turkey

${ }^{3}$ Near East University Faculty of Nursing, Department of Paediatric Nursing, Lefkosia, North Cyprus

${ }^{4}$ Bursa Uludağ University Faculty of Health Sciences, Department of Paediatric Nursing, Bursa, Turkey

${ }^{5}$ Bursa Uludağ University Faculty of Medicine, Department of Child Psychiatry, Bursa, Turkey

\begin{abstract}
Aim: This study was conducted for the purpose of determining the validity and reliability of the Parenting scale in a Turkish sample.

Materials and Methods: The study was conducted as a methodological-descriptive-cross sectional study. The study sample consisted of 355 parents who had applied to Child and Adolescent Psychiatry Polyclinic of Uludağ University. However; as 85 parents did not precisely fill the scales, they were excluded from the sample and the analyses were conducted on the basis of 270 parents. The study data were collected using the Demographic Data Collection Form and the Parenting scale. Validity analyses of the scale were examined via explanatory and confirmatory factor analysis. The internal consistency of the scale was evaluated via Cronbach alpha, Spearman-Brown and Guttman splithalf coefficients. The relationship between item-total score and item-subscale total score was examined via Pearson correlation analysis.

Results: The Cronbach alpha values of the Parenting scale were determined as; 0.935 in the lower dimension of Laxness, 0.916 in the lower dimension of Over-reactivity, 0.770 in the lower dimension of Hostility (use of verbal or physical force) and 0.829 in the total scale. The factor loads varied between; 0.52 and 0.98 in the lower dimension of Laxness, 0.75 and 0.92 in the lower dimension of Over-reactivity and 0.46 and 0.95 in the lower dimension of Hostility. It was determined that the total scale scores and correlations of items in the scale varied between 0.20-0.66. It was also determined that item-subscale total score correlations varied between; 0.61-0.96 in the lower dimension of Laxness, 0.70-0.86 in the lower dimension of Over-reactivity and 0.68-0.91 in the lower dimension of Hostility.
\end{abstract}

Conclusion: The Parenting scale is a valid and reliable tool that can be used in Turkish culture.

Keywords: Parent, parenting, scale, validity, reliability

\section{Introduction}

The family is the environment where the child's physical, social and psychological needs are met and personality development is experienced. The attitudes of parents towards their children in the family are very important in supporting children's socialization and autonomy $(1,2)$.
Parental attitudes can be defined as the sum of parents' attitudes, beliefs, behaviours and expectations about raising children and they are formed by the interaction between mother, father and child (3). There are many factors affecting the child rearing attitudes (CRA) of parents and these factors vary from family to family, from culture to culture and from society to society (4). 
The studies of Diana Baumrind provided a basis for parental attitudes $(5,6)$. Baumrind defined parenting style as a combination of parental values, attitudes, beliefs, and behaviours reflected towards the child. In 1971, she explained this concept in three different models as authoritarian, democratic and permissive parenting styles $(5,6)$. According to Baumrind, emotional support, high expectations, toleration to autonomy and a bilateral net communication style are all together in democratic attitude. This type of attitude has been found to provide the skills necessary for a better balance of personal and social needs and responsibilities of children and adolescents (7). It is also stated that parents who are warmer and supportive towards their children are more aware of their life and are less oppressive (8). The authoritarian parents expect their children to follow and obey their rules. In such families, children are punished if they do not comply with the rules and parents do not exchange many views with their children $(5,6)$. Authoritarian parents give great importance to establishing authority and immediately suppress the efforts of children to change it (9). Permissive parents give their children a lot of freedom, do not have expectations of their children, do not control their children in any way and behave with a negligent tolerance towards permission $(5,6,9)$.

It is accepted that there are two factors on the basis of parental attitudes: how much expectation and how many different types of expectations the parents have; and how much they supported their children or how much they show awareness to them. Parents' expectations of their children show how much they are willing to provide socializing to their children. Sensitive education represents the level of acceptance of parents about the individuality of their children in a sense (7). Democratic parents have both high expectations and a high level of sensitivity. In authoritarian parents, again, expectations are high, but sensitivity to their children is at a low level (7). Maccoby and Martin (9) divided Baumrind's definition of permissive parental attitudes into negligent parents and permissive parents in terms of the dimensions of demandingness and sensitivity. Negligent parents are emotionally distant from their children except to meet their basic needs, do not control or care for what is happening in the lives of their children. However, permissive parents are always concerned about and thoughtful towards their children. They do not restrain their children in any case and never punish them.

Research on parental attitudes around the world and especially in western countries is one of the most studied subjects. Also, in Turkey, many studies have been done to evaluate parental attitudes and their possible side effects.
When a search is performed in the Higher Education Board (HEB) Thesis Centre's search engine, if "mother and father (anne-baba) attitude" is researched, 40 studies are found, and similarly "mum and dad (ana-baba) attitude", 8 studies; and finally "parental (ebeveyn) attitude" 15 studies are present.

In our country, three scales have been developed to measure parental attitudes. The first one of them was the Parental Attitude Inventory developed by Kuzgun (10) in 1972, the second one is the Parental Attitude scale developed by Polat (11) (1986) and the third one is the CRA scale developed by Sümer and Güngör (12) in 1999. Data of these scales are collected from children and parental attitudes are classified.

In addition to these developed scales, there are six scales (obtainable) adapted to our language by conducting Turkish validity and reliability studies. These are the following studies: Parental Attitude Research Instrument (PARI), adapted by Le Compte et al. (13), Le Compte et al. (13) (1978); Parenting Style scale, adapted by Yilmaz (14) (2000); Parental Acceptance-Rejection QuestionnaireChild version (PARQ-Child version), its validity and reliability tested by Erdem (15) (1990); the same scale's Adult PARQ (Adult PARQ), adapted by Varan (16) (2005); the same scale adapted by Varan et al. (17) Yağmurlu (2008); and finally PARQ-Mother Form (PARQ-Mother version), adapted by Erkman and Rohner (18) in 2002. However, McMaster Family Assessment Device adapted by Bulut (19) (1990); Child-Rearing scale adapted by Yağmurlu et al. (20) (2005); Behavioral Control scale adapted by Kındap et al. (21). (2008) are among other scales in the literature. Data of the all other scales except for PARI were collected from children and parental attitudes were evaluated. At the same time, the fact that the scale items of PARI are too long makes it difficult for parents to fill in the scale and makes it difficult for researchers to use.

As is seen, although there are many scales that evaluate the attitudes of parents, it is thought that a new and more useful scale is needed to evaluate the attitudes of parents of children aged 0-12, in which data are collected from parents. Considering that the mum-dad-child interaction has differentiated qualitatively in different developmental periods, the development of individual scales that are sensitive to different age periods related to parental attitudes will be one of the most important contributions to this field $(22,23)$.

The aim of the study was to adapt the Parenting scale, developed by Rhoades and O'Leary (24) in 2007, to Turkish and to perform validity and reliability studies. 


\section{Materials and Methods}

This study was performed in a methodologicaldescriptive-cross sectional manner in order to evaluate the validity and reliability of the Parental scale in Turkey.

The research was conducted at the child psychiatry clinic between December 2014 and January 2016, in cooperation with the Faculty of Health Sciences of Uludağ University, located in the western part of Turkey and Uludağ University Research and Application Hospital.

\section{Sample}

The sample of the study was selected from parents who applied to Uludağ University Hospital Child and Adolescent Psychiatry Clinic and Polyclinic. The insertion criteria of the study was taken into consideration when selecting parents. Accordingly, the sampling characteristics are;

- Parents of children between 0-12 years of age who applied to child and adolescent psychiatry polyclinic,

- Parents of children without mental retardation, autism, psychosis, schizophrenia, bipolar disorder, obsessive compulsive disorder or pervasive developmental disorder,

- Request to participate in the study after reading informed consent form to be included in the study.

While determining the number of samples in validity and reliability studies, the literature refers to three rules: $5 \mathrm{~s}, 10 \mathrm{~s}$ and $100 \mathrm{~s}$ rule. It is emphasized that the researcher should take at least five people per item for factor analysis. If there is no problem about reaching the sampling, it is recommended that the number of persons per item should be 10 (25). However, if there are serious limitations in reaching the sampling, it is recommended that the number of samples should be at least 100 persons (25). For the validity and reliability study of the Parenting scale consisting of 30 items, the sample size was calculated as 300 children by taking 10 children per item. Three hundred fifty-five children parents who met the research criteria were included in the sample. However, 85 parents were excluded from the sample because they did not fill out the scales fully, and the analyses were performed on 270 parents. The sampling rate is $76.1 \%$.

\section{Data Collection Tools}

Data of the study were collected by using the SocioDemographic Data Collection Form and Parenting scale. The researchers gave the two forms in the clinic and the completed forms were collected by the researchers. It took an average of 25-30 minutes to complete the forms.

Socio-Demographic Data Collection Form: In this form, there are 19 questions about the child's name and age and parents' marital status, profession and education.
Parenting Scale: The original name of the scale is the "Parenting scale". It was developed in 1993 by Arnold et al. (26). In 2007, it was reorganized by Rhoades and O'Leary (24) and validity and reliability studies were performed. In our study, the revised version of 2007 was used. This 30-item scale measures non-functional disciplinary methods by asking the probabilities of certain disciplinary methods that parents use. It gives a total score and three revised factors: laxness (permissive, inconsistent discipline); over-reactivity (strict emotional authoritarian discipline and anger); and hostility (use of verbal or physical force). The scale has sufficient internal consistency. The Cronbach's Alpha values of the scale were respectively 0.85 for the laxness sub-dimension; 0.80 for the over-reactivity sub-dimension and 0.83 for the hostility sub-dimension. It was found that the scale had a good test-retest reliability in order to find the difference between the parents of children with clinical diagnosis [total score $M=3.1$, [standard deviation (SD)=0.07] and parents of children not receiving clinical diagnosis (total score $M=2.6, S D=0.06$ ) and to establish a relationship between child behaviour, marital incompatibility and depression symptoms, and between child behaviour and non-functional observational measures. All 30 items are scored on a 7-point scale. Low scores indicate good parenting, and high scores indicate non-functional parenting. There are three factors in the Parenting scale: laxness, over-reaction and hostility. The items are sorted by factors and the side of the indicator of "ideal" is shown as the right or left side. If the indicator of "ideal" is on the left, 1 point is given to the left indicator. If the indicator of "ideal" is on the right, reverse scoring is performed and 1 point is given instead of 7 to the right indicator. The total score is calculated by dividing the sum of points of all items by 30 . In order to calculate the factor score, the scores in that factor are added and this total is divided by the number of items in the factor.

\section{Data Collection}

1. Language Validity: For language validity, the scale was translated from English to Turkish independently by two English linguists whose native language is Turkish. Later, the researchers have developed a joint Turkish text by evaluating the most appropriate translation for each item. After being translated back to English by two linguists who are fluent in Turkish and English, the scale translated into Turkish was compared with its original form with the re-translation method. Inappropriate terms were reviewed and language validity was ensured.

2. Content Validity: For content validity, the draft scale was presented to 10 experts in their fields working 
in psychiatric nursing, child and adolescent psychiatry nursing and paediatric nursing. The experts were asked to evaluate the items in terms of both language and content. In order to determine content validity, the scale items were evaluated by four points as being either (a) appropriate, (b) the item should be reviewed; (c) the item must be critically reviewed; or (d) inappropriate. According to these expert answers, content validity indices for item and scale were calculated by dividing the number of experts who marked (a) and (b) by the total number of experts.

3. Implementation Phase: For the pilot scheme of the developed scale, the comprehensibility and implementation process of the developed scale were evaluated by testing the scale on parents not included in the sample.

4. Construct Validity: Explanatory and confirmatory factor analysis was used for construct validity.

5. Determination of Reliability: Cronbach-Alpha reliability coefficient, bisection and item-total score analyses were performed.

\section{Statistical Analysis}

\section{Evaluation of Data}

Parental demographic data were analysed with percentage and average. The validity analyses of the scale were analysed with explanatory and confirmatory factor analysis. The internal consistency of the scale was evaluated with Cronbach's Alpha, Spearman-Brown and Guttman split-half coefficients. The relationship between item-total score and item-subscale total scores was analysed by Pearson correlation analysis. For the validity of the scale content validity index, descriptive and confirmatory factor analysis were used. The significance level was accepted as 0.05 .

\section{Ethical Side of Research}

In order to adapt the Parenting scale to Turkish, permission was obtained via e-mail from Rhoades and O'Leary (24) (2007) who developed the scale.

In order to carry out the research, written permission was received from the Ethics Committee of Uludağ University Hospital (approval number: 2013-2/18). Written consent was obtained from the parents.

\section{Results}

\section{Content and Language Validity}

For language validity, opinions of 10 experts were received. For each item, the concordance between the experts' opinions (I-CVI) was found to be between 0.90-1.00 and 0.99 for the whole scale (S-CVI).

\section{Explanatory Factor Analysis}

In this study, Kaiser-Meyer-Olkin (KMO) value was found to be 0.660 and Bartlett's test was determined as $x^{2}=5888.904$ and $p=0.000$. As a result of explanatory factor analysis, the data were collected under three subdimensions. The first sub-dimension accounted for $36.7 \%$ of the total variance, the second sub-dimension accounted for $27.4 \%$ and the third sub-dimension $13.5 \%$. The three sub-dimensional scales accounted for $77.6 \%$ of the total variance. The factor loads of the first sub-dimension ranged from 0.52 to 0.98 . The factor loads of the second subdimension ranged between 0.75 and 0.92 . The factor loads of the third sub-dimension ranged from 0.46 to 0.95 (Table I).

As a result of confirmatory factor analysis, factor loads in the first sub-dimension ranged from 0.43 to 0.99 in three sub-dimensional models. The factor loads of the second sub-dimension are between 0.49-0.99. The factor loads of the third sub-dimension ranged between 0.36 and 0.97 (Table II). Model fit indicators were determined as $\mathrm{CFI}=0.93$, $\mathrm{CFI}=0.98, \mathrm{IFI}=0.98, \mathrm{NFI}=0.96, \mathrm{NNFI}=0.97$ and $x^{2}=127.55$, $\mathrm{df}=58, \mathrm{p}=0.000$ and RMSEA $=0.067$ (Figure 1).

\section{Reliability Analysis}

The total sub-dimensions of the scale were 0.829, $0.935,0.916$ and 0.770 , respectively. In this study,

\begin{tabular}{|l|l|l|l|}
\hline \multirow{2}{*}{ Table I. Explanatory factor analysis results } \\
\hline \multirow{2}{*}{ Items } & \multicolumn{3}{|c|}{ Factor loads } \\
\cline { 2 - 4 } & Laxness & Overreaction & Hostility \\
\hline $3^{\text {rd }}$ Item & - & 0.93 & - \\
\hline $6^{\text {th }}$ Item & - & 0.75 & - \\
\hline $10^{\text {th }}$ Item & - & 0.75 & - \\
\hline $12^{\text {th }}$ Item & 0.98 & - & - \\
\hline $14^{\text {th }}$ Item & - & 0.92 & - \\
\hline $16^{\text {th }}$ Item & 0.97 & - & - \\
\hline $17^{\text {th }}$ Item & - & 0.91 & - \\
\hline $18^{\text {th }}$ Item & - & - & 0.46 \\
\hline $19^{\text {th }}$ Item & 0.52 & - & - \\
\hline $21^{\text {st }}$ Item & 0.98 & - & - \\
\hline $25^{\text {th }}$ Item & - & - & 1.751 \\
\hline $28^{\text {th }}$ Item & - & - & 0.95 \\
\hline 30th Item & 0.98 & - & 0.95 \\
\hline Explained Variance (\%) & 36.7 & 27.4 & - \\
\hline $\begin{array}{l}\text { Total Explained } \\
\text { Variance (\%) }\end{array}$ & 77.6 & - & 13.5 \\
\hline Eigenvalue & 4.771 & 3.564 & - \\
\hline
\end{tabular}


Cronbach's Alpha, Spearman-Brown and Guttman splithalf are above 0.70 . In this study, the maximum and minimum values of the total and subscale scores of the scale are below $20 \%$.

The correlations of the items in the scale with the total score of the scale were identified as ranging from 0.20 to 0.66. Item-subscale total score correlations ranged from 0.61-0.96 for the first sub-dimension; and 0.70-0.86 for the second sub-dimension and 0.68-0.91 for the third subdimension (Table III).

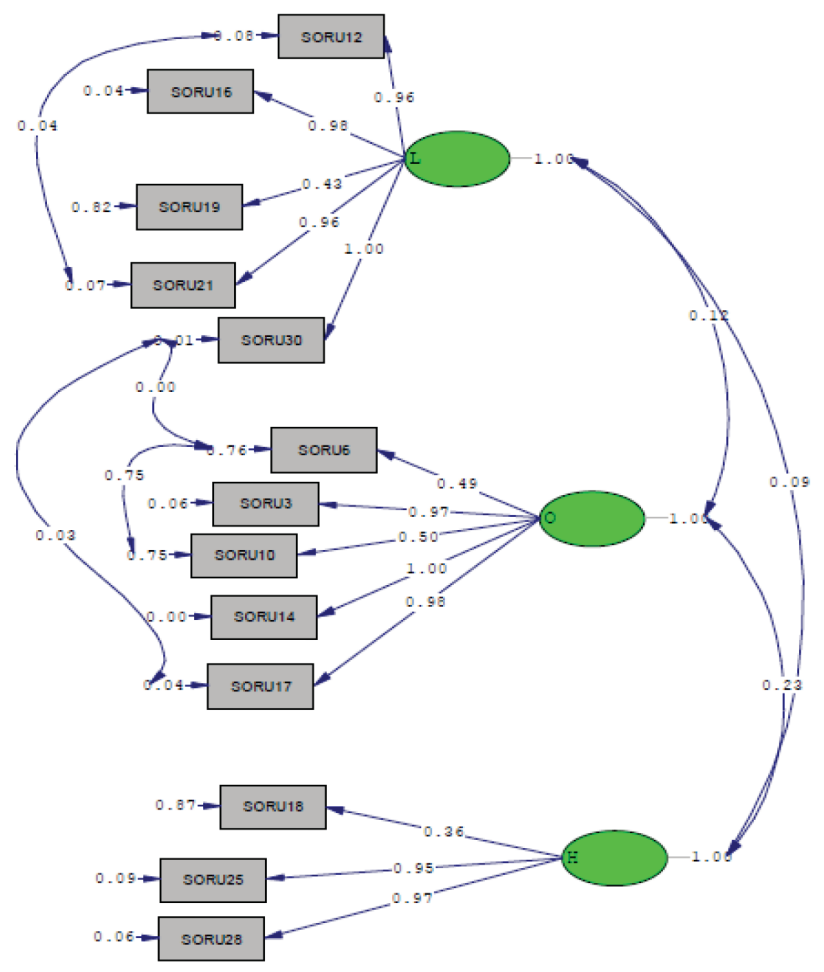

Chi-Square $=127.55, d f=58, P-$ value $=0.00000$, RMSEA $=0.067$

Figure 1. Confirmatory factor analysis

\section{Discussion}

The opinions of ten experts were obtained for the validity of language and content. For both language and content validity, the fit indices were found to be above 0.90 both on item and scale basis. The results of I-CVI and $\mathrm{S}-\mathrm{CVI}$ in this study showed that there was concord between the experts, that the language validity of the scale was achieved, that the scale measures the subject adequately and that the content validity was achieved (27-29).

\section{Validity Analysis}

The appropriateness of the obtained data and the factor analysis of the sampling size were evaluated by use of the KMO coefficient and Bartlett's test. Being greater than 0.60 for the KMO value and the meaningfulness of the Bartlett's test indicates that the database is appropriate for factor analysis and the number of samples is sufficient for factor analysis. In this study, the KMO value was 0.60 and Bartlett's test was $p<0.05$. These results indicate that the data are appropriate for factor analysis. In this study, it was determined that the three sub-dimensions revealed $77.6 \%$ of the total variance. According to the explanatory factor analysis, the factor loads were found to be above 0.40 in all sub-dimensions. While the total variance explained in the literature is considered to be between $40-60 \%$, to be above $50 \%$ for this value is accepted as evidence for a strong construct validity. In this study, both the greatness of the explained variance and being above 0.40 for all factor loads in all the sub-dimensions showed that the scale had a strong structure validity in the Turkish sample $(25,27-33)$. In addition, the factor loads on the original scale were found to be over 0.30 for both mothers and fathers (24) and the original scale factor loads were compatible with the results of this study. Since the total variance was not given in the original study, the total variance rates of the two studies could not be compared.

Table II. Model fit indices of confirmatory factor analysis

\begin{tabular}{|l|l|l|l|l|l|l|l|l|l|l|l|}
\hline Models & $\boldsymbol{X}^{\mathbf{2}}$ & $\mathbf{D f}$ & $\mathbf{p}$ & $\boldsymbol{\chi}^{\mathbf{2}} / \mathbf{d f}$ & $\mathbf{R M S E A}$ & $\mathbf{G F I}$ & $\mathbf{C F I}$ & IFI & NFI & NNFI & RFI \\
\hline Model 3 (three sub-dimensional model) & 127.55 & 58 & 0.000 & 2.19 & 0.067 & 0.93 & 0.98 & 0.98 & 0.96 & 0.97 & 0.95 \\
\hline
\end{tabular}

Table III. Reliability analysis of scale and sub-dimensions ( $n=270)$

\begin{tabular}{|l|l|l|l|l|l|l|l|}
\hline Scale & Cronbach $\alpha$ & Spearman-Brown & Guttman split-half & mean \pm SD & Min-Max & Floor effect \% & Ceiling effect \% \\
\hline Laxness & 0.935 & 0.919 & 0.939 & $3.45 \pm 1.71$ & $1-7$ & 5.9 & 3.3 \\
\hline Overreaction & 0.916 & 0.842 & 0.846 & $3.62 \pm 1.48$ & $1-7$ & 5.6 & 2.2 \\
\hline Hostility & 0.770 & 0.781 & 0.807 & $2.81 \pm 1.29$ & $1-6.67$ & 15.6 & 0.0 \\
\hline Total Scale & 0.829 & 0.733 & 0.721 & $3.69 \pm 0.82$ & $1.20-6.67$ & 0.0 & 0.0 \\
\hline
\end{tabular}

$\alpha$ : alpha, SD: Standard deviation, Min: Minimum, Max: Maximum 
As a result of the confirmatory factor analysis in this study, factor loads in the first sub-dimension ranged from 0.43 to 0.99 in the three sub-dimensional models. The factor loadings of the second sub-dimension are between 0.49-0.99. It was determined that the factor loads of the third sub-dimension ranged between 0.36-0.97. Model fit indicators were found to be greater than $0.90(\mathrm{GFI}=0.93$, $\mathrm{CFI}=0.98, \mathrm{IFI}=0.98, \mathrm{NFI}=0.96, \mathrm{NNFI}=0.97), \mathrm{x}^{2} / \mathrm{df}$ ratio was less than five (5) and RMSEA was found to be less than 0.08 (Figure 1). As a result of DFA, it was determined that the factor loads of all sub-dimensions were over 0.30, the fit indices were above 0.90 and the RMSEA was below 0.08 . If the Model fit indicators are $>0.85, \mathrm{x}^{2} / \mathrm{df}$ is less than five and RMSEA $<0.08$, than it is considered as a good fit indicator in the literature. The CFA results in this study showed that the data were compatible with the model, that the data confirmed the three-factor structure, that the subdimensions were related to the scale and that the items in each sub-dimension defined their own factor as sufficient. On the original scale, the fit indices for both mothers and fathers were found to be above 0.90, RMSEAs were below 0.08 and $x^{2} / d f$ was below 5 . The results of this study were similar to the results of the DFA for both mothers and fathers in the original study (24). This similarity showed that the Turkish version of the scale had a similar structure with the original scale and the structure validity of the Turkish version was obtained.

The results of the explanatory and confirmatory factor analysis in this study reveal that the scale is a valid tool by supporting the construct validity of the scale.

\section{Reliability Analysis}

The Cronbach Alpha coefficient indicates whether the items measure the same characteristics and whether the items are relevant to the subject to be measured. In the scales, this value is to be as close to 1 as possible. When this value is between 0.60 and 0.80 , it indicates that the scale is fairly reliable; and between 0.80 and 1.00 means that it is highly reliable $(25,27-34)$. In this study, the Cronbach Alpha coefficients of the total and sub-dimensions of the scale were found to be greater than 0.70 . This result showed that both the full scale and the sub-dimensions of the scale are highly reliable. The values obtained from the study showed that the items were able to measure the desired level adequately, that the items were related to the subject and that the scale had a very good reliability $(25,27-33)$. Also, in the original study, it was determined that the corrected Cronbach Alphas for both mothers and fathers were over 0.70 (24). This result shows that the scale is similar to the original structure and that the scale has a strong internal consistency.
In the split half method used in this study, it was found that the Cronbach's Alpha values of both sections were above 0.70; a strong and significant relationship was found between the two halves and both Spearman-Brown and Guttman Split-Half coefficients were found to be more than 0.80 . These results showed that the scale has a high level of reliability $(25,27-33)$. While these results showed that the internal validity of the scale was high; since these analyses were not given in the original study, the results of this study were not compared with the original scale results. In this study, maximum and minimum values of the total score and subscale scores of the scale were found to be less than $20 \%$. In the literature, it is emphasized that the maximum and minimum values are indicators of the homogeneity of the scale, that this value should be below $20 \%$ and that provides evidence for both validity and reliability $(25,27-32,34)$. Also, in this study, the fact that this value is below the limit indicates that the scale is a reliable tool by supporting the construct validity of the scale $(25,27-33)$.

The item-total score analysis shows the relationship between the scores of the scale items and the total score of the scale. It is evidence that the items in the scale measure the desired quality $(25,27-33)$. This value should be greater than 0.20 and in a positive direction (25). In this study, the correlations of the items with the scale total score ranged between 0.20-0.66; and the correlations of the items with the subscale total score ranged between 0.61-0.96. It was found that the correlation coefficients of both the item-total score and the item-subscale were in a positive direction and greater than 0.20 . According to these results, it was found that all items of the scale had a high correlation with the total score and total score of their sub-dimensions, that the scale was able to measure the desired quality and that the reliability of the scale and the sub-dimensions were high. Since the item-total score and item-subscale total score correlations were not given in the original study, the scale results could not be compared with the original scale (24).

\section{Study Limitations}

Despite all its strengths, the scale has a few limitations. These limitations are that the study was conducted only in the western part of the country and with the use of a random sampling method. These limitations may affect the generalization of the results of the study.

\section{Conclusion}

The results of this study show that the scale is a valid and reliable measurement tool for the Turkish sample. The scale is a valid and reliable tool that can be used to 
examine the disciplinary methods used by Turkish parents. Using this scale is recommended to conduct studies in both healthy and clinical samples and to plan studies in which intercultural comparisons can be made.

\section{Ethics}

Ethics Committee Approval: Written permission was received from the Ethics Committee of Uludağ University Hospital (approval number: 2013-2/18).

Informed Consent: Written consent was obtained from the parents.

Peer-review: Externally peer-reviewed.

\section{Authorship Contributions}

Surgical and Medical Practices: B.A., M.B., C.Ö., N.Ö., P.V., Concept: B.A., M.B., C.Ö., Design: B.A., M.B., Data Collection or Processing: B.A., N.Ö., P.V., Analysis or Interpretation: B.A., M.B., C.Ö., Literature Search: B.A., M.B., C.Ö., N.Ö., Writing: B.A., M.B., C.Ö., N.Ö., P.V.

Conflict of Interest: Authors declare that there is no conflict of interest regarding the publication of this paper.

Financial Disclosure: The authors declared that this study received no financial support.

\section{References}

1. Belli M. Ergenlerde algılanan ebeveyn tutumu, akıllı telefon kullanımı ve sosyal kaygı arasındaki ilişkinin incelenmesi. Kütahya Sağlık Bilimleri Üniversitesi Lisansüstü Eğitim Enstitüsü, hemşirelik programı yüksek lisans tezi. 2018 (an examination of the association between perceived parental attitude, smartphone use and social anxiety among adolescents. Kütahya Health Sciences University Graduate İnstitute, nursing program master's thesis, kütahya. 2018).

2. Çevikbaş EP. Ortaokul Ve Lise Öğrencilerinin Adil Dünya İnançlarının Denetim Odağı Ve Anne Baba Tutumu Açısından Gelişimsel Olarak İncelenmesi, Hacettepe Üniversitesi Sağlık Bilimleri Enstitüsü, Çocuk Gelişimi ve Eğitimi Programı, Doktora Tezi. 2018. (Developmental Investigation of Middle and High School Students' Beliefs in a Just World in Terms of Locus of Control and Parental Attitudes, Hacettepe University Institute of Health Sciences Child Development and Eduation Program Doctor of Philosophy Thesis, Ankara, 2018).

3. Yenihayat T. Üniversite Öğrencilerinin Kimlik Statüleri, Kişilik Özellikleri ve Algıladıkları Ebeveyn Tutumları Arasındaki İlişkilerin İncelenmesi. İstanbul Üniversitesi, Yüksek Lisans Tezi. 2011 (The Relations Between Identiy Statuses, Personality Traits And Perceived Parenting Styles. Istanbul University, Institute of Social Sciences, Master's Thesis, 2011).

4. Özyürek A, Özkan i. Ergenlerin algıladıkları anne baba tutumları ile sosyal beceri düzeyleri arasındaki ilişkinin incelenmesi (A Study on the Relationship between Adolescents' Perception the Parental Attitudes and Their Social Competence Level). International Journal of Science Culture and Sport, 2015:75-6.

5. Baumrind D. Harmonious parents and their preschool children. Devel Psych 1971;4:99-102.

6. Baumrind D. The influence of parenting style on adolescent competence and substance use. J Early Adolesc 1991;11:56-95.
7. Darling N, Steinberg L. Parenting styles as context: an integrative model. Psychol Bull 1993;113:487-96.

8. Patterson MW, Cheung AK, Mann FD, Tucker-drob EM, Harden KP. Multivariate Analysis of Genetic and Environmental Influences on Parenting in Adolescence. J Fam Psychol 2017;27:110.

9. Maccoby EE, Martin JA. Socialization in the context of the family: Parent-child interaction. P.H. Mussen \& E.M. Hetherington (Eds.). Handbook of Child Psychology: Socialization, Personolity and Social Development (pp. 1-101) New York: Wiley. 1983.

10. Kuzgun Y. Ana-baba tutumlarının bireyin kendini gerçekleştirme düzeyine etkisi. Yayınlanmamış Doktora Tezi. Ankara: Hacettepe Üniversitesi, Eğitim Bölümü. 1972.

11. Polat S. Ana-baba tutumlarının öğrenilmiş çaresizlik düzeyine etkisi. Yayınlanmamış Yüksek Lisans Tezi. Ankara: Hacettepe Üniversitesi.1986.

12. Sümer N. Güngör D. Çocuk yetiştirme stillerinin bağlanma stilleri, benlik değerlendirmeleri ve yakın ilişkiler üzerindeki etkisi (The interplay between the perceived parenting styles of the university students and attachment styles, basic selfdimensions, behavior patterns in close relationships and relationship satisfaction). Türk Psikoloji Dergisi 1999;14:35-58.

13. Le Compte G, Le Compte, A, Özer SA. Üç sosyoekonomik düzeyde, Ankaralı annelerin çocuk yetiştirme tutumları: Bir ölçek uyarlaması. Psikoloji Dergisi 1978;1:5-9.

14. Yılmaz A. Anne-Baba Tutum Ölçeğinin Güvenirlik ve Geçerlik Çalışması (Parenting Style Scale: Reliabilitiy And Validity). Çocuk ve Gençlik Ruh Sağlığı Dergisi 2000;7:160-72.

15. Erdem T. The validity study of Turkish form of Parental Acceptance-Rejection Questionnaire. Yayınlanmamış Yüksek Lisans Tezi, İstanbul: Boğaziçi Üniversitesi, Eğitim Fakültesi, Eğitim Bilimleri Bölümü. 1990.

16. Varan A. Relation between perceived parental acceptance and intimate partner acceptance in Turkey: Does history repeat itself? ETHOS 2005;33:414-26.

17. Varan A. Rohner RP. Eryuksel G. Intimate partner acceptance, parental acceptance in childhood, and psychological adjustment among Turkish adults in ongoing attachment relationship. Cross-Cultural Research 2008;42:46-56.

18. Erkman F. Rohner RP. Youths' perceptions of corporal punishment, parental acceptance, and psychological adjustment in a Turkish metropolis. Cross Cultural Research 2006;40:250-67.

19. Bulut I. Aile Değerlendirme Ölçeği Elkitabı. Ankara: Özgüzeliş Matbaası 1990.

20. Yağmurlu B, Sanson A. Köymen SB. Ebeveynlerin ve çocuk mizacının olumlu sosyal davranış gelişimine etkileri: Zihin kuramının belirleyici rolü (Effects of Parenting and Child Temperament on the Development of Prosocial Behavior: The Mediating Role of Theory of Mind). Türk Psikoloji Dergisi 2005;20:1-20.

21. Kındap $Y$, Sayıl M, Kumru A. Anneden algılanan kontrolün niteliği ile ergenin psikososyal uyumu ve arkadaşlıkları arasındaki ilişkiler: Benlik değerinin aracı rolü (The Relationships Among Type of Perceived Maternal Control, Psychosocial Adjustment, and Friendship in Adolescence: The Mediator Role of Self-Esteem). Türk Psikoloji Dergisi 2008;23:92-107.

22. Demir KE, Şendil G. Ebeveyn Tutum Ölçeği (ETÖ) (Parent Attitude Scale (PAS) Türk Psikoloji Yazıları 2008;11:15-25.

23. Sümer N, Aktürk GE, Helvacı E. Anne-Baba Tutum ve Davranışlarının Psikolojik Etkileri: Türkiye'de Yapılan Çalışmalara 
Toplu Bakış (Psychological Effects of Parenting Styles and Behaviors: A Review of Studies in Turkey). Türk Psikoloji Yazıları Haziran 2010;13:42-59.

24. Rhoades KA, O'Leary SG. Factor Structure and Validity of the Parenting Scale. J Clin Child Adolesc Psychol 2007;36:137-46.

25. Şencan $H$. Sosyal ve davranışsal ölçümlerde güvenilirlik ve geçerlilik (reliability and validity in cocial and behavioral measurement). 1.edition, Ankara: Seçkin Yayınevi, 2005.

26. Arnold DS, O'Leary SG, Wolff LS, Acker MM. The Parenting Scale: A Measure of Dysfunctional Parenting in Discipline Situations. Psychological Assessment 1993;5:137-44.

27. Polit DF, Beck CT, Owen SV. Is the CVI an acceptable indicator of content validity? Appraisal and recommendations. Res Nurs Health 2007;30:459-67.

28. Rattray J. Jones MC. Essential elements of questionnaire design and development. J Clin Nurs 2007;16:234-43.
29. Terwee $C B$, Bot $S D$, de Boer $M R$, van der Windt $D A$, Knol DL, Dekker I, Bouter LM, de Vet HC. Quality criteria were proposed for measurement properties of health status questionnaires. I Clin Epidemiol 2007;60:34-42.

30. Aksayan S, Gözüm S. Kültürlerarası Ölçek Uyarlaması için Rehber I: Ölçek Uyarlama Aşamaları ve Dil Uyarlaması. Hemşirelik Araştırma Dergisi 2002;4:9-14.

31. Özdamar K. Paket Programlar ile İstatistiksel Veri Analizi. 4. Baskı. Eskişehir: Kaan Kitabevi; 2005:661-73.

32. Simşek ÖF. Yapısal Eşitlik modellemesine giriş temel ilkeler ve LISREL Uygulamaları (Introduction to Structural Equation Modeling, LISREL Fundamental Principles and Practices). İstanbul: Ekinoks, 2010.

33. DeVellis RF. Scale development, theory and Applications. 3rd ed. India, SAGE Publication Inc, 2012;31-59.

34. Hayran M. Basic statistic for health researh. Ankara, Art Ofset Matbacılık Yayıncılık Org. Ltd Şti, 2011;132-332. 